\title{
Pastoralno djelovanje s rastavljenima i civilno vjenčanima prema pobudnici Amoris laetitia
}

\author{
StANiSLAv ŠOTA* \\ UDK: 272-732.2-454Franciscus, papa • Pregledni članak \\ Primljeno: 7. siječnja 2017. Prihvaćeno: 8. svibnja 2017.
}

Sažetak: Papa Franjo učinio je do sada jedinstven korak u Crkvi sazvavši dvije uzastopne biskupske sinode obitelji i time je pokazao koliki mu je obitelj prioritet i pastoralni izazov. Pobudnica Amoris laetitia izazvala je veliku pozornost u crkvenim i sekularnim krugovima, posebno njezino osmo poglavlje u kojemu je naznačeno kako pratiti, razlučivati i integrirati slabosti rastavljenih i civilno vjenčanih. Papa polazi od konkretne pastoralne situacije koju teološki oblikuje i tumači, stoga je taj kerigmatski pristup ključ za razumijevanje pobudnice. Papi su posebno na srcu teškoće s kojima se suvremena obitelj susreće, stoga obiteljima u izvanrednim situacijama prilazi poput milosrdnoga oca koji ih osluškuje, prihvaća, nudi načine inte-

${ }^{*}$ Doc. dr. sc. Stanislav gracije. Nužna je prementalizacija, posebice kod predvoditelja Šota, Katolički bogoslovni fakultet u Đakovu Sveučilišta J.J. Strossmayera u Osijeku, P. Preradovića 17, 31400 Đakovo, Hrvatska, stanislav. sota@os.t-com.hr župnih zajednica, svećenika i ostalih pastoralnih djelatnika. Svećenikovo praćenje rastavljenih $i$ civilno vjenčanih in foro interno mora omogućiti ispravan sud o poteškoćama $i$ zaprekama punoga sudjelovanja u životu Crkve te stvarati pozitivne korake koji trebaju pogodovati, omogućavati i pospješiti pastoralno djelovanje. Očitovanje teškoća u ostvarivanju sakramentalne milosti u sakramentu ženidbe nužno zahtijeva otkrivanje djelomičnih krjeposti koje rastavljeni $i$ civilno vjenčani mogu ostvariti. Uskogrudno promatranje koje nije ugradilo pastoralno razlučivanje, prosudbu i praćenje traži iskorak pastoralne djelatnosti. Pastoral ne bi trebao biti statičan, nego kreativan $i$ poletan, odnosno prožet iskoracima koji omogućavaju objavu Božje pedagogije milosti svakom čovjeku.

Ključne riječi: Amoris laetitia, pratiti, razlučivati, integrirati, rastavljeni i civilno vjenčani, brak, in foro interno. 


\section{Uvod}

Promišljanje kardinala Waltera Kaspera o usporedbi i razlici u pristupu teološkopastoralnoj problematici pape Benedikta XVI. i pape Franje uvelike nam može približiti namjere, želju te bit pastoralnih postavki pape Franje u odnosu na brakove koji su rastavljeni i civilno vjenčani. Kasper kaže: »Benedikt XVI polazi od vjere Crkve, pokušavajući je na duhovan način otvoriti razumijevanju, da bi potom - $\mathrm{u}$ skladu s tradicionalnim određenjem odnosa između teorije i prakse - nauk vjere pretočio u praksu. Njegov je jezični stil duhovno promišljen i proživljen nauk. Nasuprot tomu, papa Franjo određen je kerygmatskom teologijom kao što je bio i Ignacije Loyolski. $\ll^{1}$ Rahner bi rekao da je riječ o spoznaji konkretne Božje volje upućene svakom pojedincu, ${ }^{2}$ a to znači da papa Franjo polazi od konkretne pastoralne situacije koju teološki oblikuje i tumači. Sazivanjem sinode o pastoralnim izazovima za obitelj u kontekstu evangelizacije pokazao je kako on zamišlja pastoralno djelovanje. Po njemu sinodalni proces započinje anketom, izvanrednom biskupijskom sinodom, kako bi se razjasnio status questionis o kojem se raspravljalo u mjesnim Crkvama i na biskupijskim konferencijama, relacijama koje je dobio te na kraju redovite sinode 2015. godine. Prema papi Franji pastoral braka i obitelji u svim aspektima treba biti šire i otvorenije postavljen, posebice jer »unatoč znacima krize u koju je zapala obitelj kao institucija, ipak još uvijek, u najrazličitijim okruženjima, mladi naraštaji njeguju i posjeduju želju za osnivanjem vlastite obitelji $\ll^{3}$. Pastoral braka i obitelji stoga mora imati svoj cilj, svrhu i sadržaj. Pastoralno djelovanje nikako ne bi smjelo biti introvertirano, zatvoreno u sebe i svrha sebi, nego ono treba pokazati veću prilagodljivost ${ }^{4}$, a predvoditelji župnih zajednica naglašeniju misijsku poučljivost i kreativnost. ${ }^{5}$ Papa Franjo u pastoralnom djelovanju s najranjivijima, onima kojima treba vidati rane, rastavljenima i civilno vjenčanima, vidi istu strukturu kao i u župi i župnoj zajednici: fizičku, ${ }^{6}$ pastoralnu ${ }^{7}$ i sakramentalnu strukturu. ${ }^{8}$

${ }^{1}$ W. KASPER, Papa Franjo revolucija nježnosti i ljubavi, Zagreb, 2015., 20.

${ }^{2}$ Usp. isto, 21.

${ }^{3}$ XIV OPĆA REDOVITA SKUPŠTINA BISKUPSKE SINODE, Relatio finalis - zaključno izvješće biskupske sinode, Zagreb, br. 2, 8.

${ }^{4}$ Usp. M. ŠIMUNOVIĆ, Pastoralna teologija u misionarskoj situaciji, u: P. ARAČIĆ, (ur.) Novi izazovi pastoralne teologije, Đakovo, 2005., 43-46.

${ }^{5}$ Usp. FRANJO, Evangelii gaudium, Zagreb, 2013., br. 28, 28. (= EG).

${ }^{6}$ Fizička struktura znači da su prostori u župi za svakoga pojedinca uvijek otvoreni. Usp. isto.

${ }^{7}$ Pastoralna struktura znači da je župna zajednica na čelu sa župnikom otvorena svima u smislu sudjelovanja i angažiranosti, posebice prihvaćenosti različitih vidova ostvarenja puta svetosti, Božje volje i Božje pedagogije. Usp. isto.

${ }^{8}$ Sakramentalna struktura znači da se sakramenti ne bi smjeli uskraćivati iz »jednostavno bilo kojega razloga «. Potrebno je vrlo oprezno, pažljivo, nježno, osjetljivo, s ljubavlju, osobno pristupiti svakoj osobi koja traži sakramente. Usp. isto. 
Prvi dio rada ukratko prikazuje životni kontekst današnjih obitelji. Budući da su pojedina razilaženja sinodalnih otaca o nekim pitanjima braka i obitelji, posebice o rastavljenima i civilno vjenčanima, podigla velika medijsku prašinu, drugi dio rada prikazuje koja su očekivanja od sinode i pobudnice. Treći dio rada donosi upute praćenja razlučivanja i integriranja slabosti rastavljenih i civilno vjenčanih prema pobudnici Amoris laetitia te objašnjava razgovor svećenika in foro interno kao svojevrsni pastoralni novum u pastoralnom djelovanju s njima. Papa Franjo smatra da rastavljenima i civilno vjenčanima, kao i brakovima koji žive u neredovitim i redovitim okolnostima ili situacijama, ne treba predočavati ${ }^{9}$ pravila, nego predlagati vrjednote koje će postupno obogaćivati, doprinositi i omogućavati rast u njihovoj vjeri. ${ }^{10}$

\section{1. Životni kontekst današnjih brakova i obitelji općenito, posebice rastavljenih i civilno vjenčanih prema pobudnici Amoris laetitia}

Suvremena kultura institucionalizirane materijalne moći ima za cilj relativizirati mnoge institucije, tako i Crkvu. U tom kontekstu pastoral i pastoralno djelovanje s rastavljenima i civilno vjenčanima, prema papi Franji, uz sveprisutnu sekularizaciju, treba uzeti u obzir uvjetovanosti na kulturno-društvenoj, političkoj i ekonomskoj razini. ${ }^{11}$ Nove ideologije kao što su diktatura relativizma ${ }^{12}$ i rodna ideologija ${ }^{13}$ uništavaju antropološki temelj obitelji i promiču društvo bez spolne razlike. Za promotore diktature relativizma ${ }^{14}$ i rodne revolucije ljudski identitet prestaje biti prirodna danost kao muškoga i ženskoga bića te je svaki čovjek prepušten hirovitom izboru pojedinca. Relativizirajući antropološku dimenziju obitelji i braka, posebice Božji naum s muškarcem i ženom, rodna ideologija niječe bitnu biološku razliku između muškarca i žene i njihovu komplementarnost te prirodno međusobno usmjerenje. Ljudski identitet na taj je način prepušten individualnoj opciji koja korjenito niječe biološku razliku između muškarca i žene. ${ }^{15}$ Antropologiju koju Crkva nastoji približiti današnjem čovjeku, naglašavajući kako je čovjek stvoren na sliku i priliku Božju, postmoderni suvremeni čovjek često ne uspijeva razumjeti. Antropološku dimenziju braka i obitelji u biblijskom smislu čovjek ne smatra do-

\footnotetext{
${ }^{9}$ Usp. XIV OPĆA REDOVITA SKUPŠTINA BISKUPSKE SINODE, Relatio finalis - zaključno izvješće biskupske sinode, br. 32, 39.

${ }^{10}$ Usp. FRANJO, Amoris laetitia, Zagreb, 2016., br. 201, 154. (= AL).

${ }^{11}$ Usp. isto, br. 201, 154.

${ }^{12}$ Usp. R. de MATEI, Diktatura relativizma, Split, 2010., 61.-114.

${ }^{13}$ Usp. G. KUBY, Nova ideologija seksualnosti, Split, 2010., 21.-124.

${ }^{14}$ Usp. I. ŠOLA, Teološka bilježnica, Osijek, 2006., 15.-16.

${ }^{15}$ Usp. G. KUBY, Nova ideologija seksualnosti, 21.-124.
} 
voljno aktualnom, privlačnom i autentičnom. Prožet diktaturom relativizma postavlja pitanje i o humanosti ljudske seksualnosti te ukorijenjenosti ljudske spolnosti u ljudsku osobnost. ${ }^{16} \mathrm{Na}$ ekonomskoj razini beskrupulozni kapitalizam ima za cilj samo dobit. Tako su mnoge obitelji u mnogim državama uvelike ugrožene. Naime, nositelji obitelji, očevi i majke, na poslu su često izloženi mobingu, potplaćenosti, prekomjernom i duljem radnom vremenu. Često se događa da se današnji čovjek nalazi u dvjema krajnostima, prezaposlenosti ili nezaposlenosti. Svjestan da je danas ključni problem nezaposlenost i prezaposlenost, ${ }^{17}$ Papa u više navrata govori o dostojanstvu rada, ali i odmora. Svjestan je da je Crkva, govoreći o radu i odmoru obiteljskih osoba, poput Davida u susretu s Golijatom. Zbog toga Papa poziva obitelji da još dublje urone u vjeru, molitvu i kršćansku zajednicu kako bi ublažili ono što se ne može pobijediti. ${ }^{18}$ Prezaposlenost ili nezaposlenost dakle sustavno i na dulje vrijeme razaraju brak i obitelj, stvaraju preduvjet za diskriminaciju i siromaštvo mnogih obitelji s jedne strane, a s druge strane prekomjerno bogaćenje pojedinaca. ${ }^{19}$ Mnoštvo ponuda, zabave, ovisnosti o televiziji, internetu, kocki, drogi, alkoholu, tjeskoba i distres ${ }^{20}$, prema Papi, nisu samo razarajuće stvarnosti i okolnosti za brak i obitelj nego postaju i sastavni problemi mnogih kultura danas. ${ }^{21} \mathrm{Sel}-$ fie-kultura te sve naglašeniji potrošački svijet i mentalitet dodatno opterećuju kulture, a brak i obitelj postaju nepoželjna institucija. Postmoderni svijet i mentalitet prožet je dakle agresivnom dekonstrukcijom obitelji i braka koja ugrožava njegovu egzistenciju kao temeljnu jezgru ljudskoga društva. ${ }^{22}$ Sazvavši u vrlo kratkom vremenu dvije sinode o braku i obitelji, papa Franjo pokazuje da je svjestan činjenice da se, unatoč želji mnogih da sklope brak i zasnuju obitelj, stvara kultura u kojoj brak kao institucija gubi važnost. Mnogi mladi boje se i strahuju od sklapanja braka. Današnji mladi imaju pred sobom mnogobrojna negativna iskustva rastave vlastitih roditelja, prijatelja i rodbine s jedne strane, a s druge strane Crkva dovoljno kvalitetno pastoralno ne djeluje ili je prožeta osjećajem nemoći između nauka i konkretne situacije. ${ }^{23}$ Kriza braka, a time i obitelji, danas se očituje u tome što osobe zbog

\footnotetext{
${ }^{16}$ Usp. T. MILIKIĆ, Je li ljudska seksualnost humana i osobna?, u: Obnovljeni život 71(2016.)4, 449.462.

${ }^{17}$ Usp. AL, br. 50-51, 41.-42.

${ }^{18}$ Usp. FRANJO, Obitelj je dragocjeno blago, Split, 2015., 125.-136.

${ }^{19}$ Usp. isto, 131.-136.

${ }^{20}$ Stres je pozitivna stvarnost, distres je negativna. Distres označava stanje kada pojedinac više ne može kontrolirati stresove. Usp. V. GRUDEN, Ožiljci na duši Hrvatske, Zagreb, 1996.

${ }^{21}$ Usp. AL, br. 50, 41.-42.

${ }^{22}$ Usp. J. BALOBAN, G. ČRPIĆ, Brak - institucija od koje se očekuje a u koju se ne ulaže, u: J. BALOBAN (ur.), U potrazi za identitetom, Zagreb, 2005., 115.-143.
}

${ }^{23}$ Usp. AL, br. 36-41, 28.-32. 
osobnih i njima poznatih razloga ne žele sklopiti odmah i crkvenu ženidbu, nego samo građansku ženidbu. ${ }^{24}$ Životna zajednica prožeta neobveznošću sigurno ima u sebi ne samo osobne razloge nego je i splet mentaliteta i svijeta u kojem živimo te svjetonazorskih, kulturnih i društvenih okolnosti. Na audijenciji 27. svibnja 2015. ${ }^{25}$ godine papa Franjo progovara i o zaručništvu, vrlo aktualnoj temi pastorala braka i obitelji, temi koja je gotovo iščezla, a koja u velikoj mjeri po mnogima utječe na moguću krizu i rastavu. Za zaručništvo Papa kaže: »Zaruke su životni put koji mora postupno sazrijevati poput voća, to je put sazrijevanja u ljubavi, sve do trenutka sklapanja ženidbe. Čekati taj trenutak; to je trenutak, to je put kojim se polako ide naprijed, ali je hod sazrijevanja. Etape toga puta se ne smiju preskakati. Sazrijeva se korak po korak. Vrijeme zaruka može doista postati vrijeme inicijacije, ali za što? Za iznenađenje! Za iznenađenje duhovnih darova kojima Gospodin, po Crkvi, obogaćuje obzor nove obitelji koja je spremna živjeti u njegovu blagoslovu. ${ }^{26}$ Današnji svijet i čovjek, posebice u našim zapadnim društvima i među krštenima, brak i obitelj više ne poimaju i ne doživljavaju kao Radosnu vijest. ${ }^{27}$ To je istinski, prema papi Franji, pastoralni problem. On želi otvoriti novi put navještaja Radosne vijesti o braku i obitelji za život cijele Crkve. Mnogi su mladi danas zaručništvo zamijenili dugotrajnim zajedničkim životom, slobodnim vezama, a slavlje ženidbe kao sklapanje ženidbenoga saveza zatraže nakon što su dugo živjeli zajedno. ${ }^{28}$ Pastoral prožet posebnom pažnjom, napose u susretu s necjelovitim vidom zaručništva, treba u sebi sadržavati duh razlučivanja situacije gotovo od jednoga bračnoga para do drugoga. Duh razlučivanja u pastoralnom smislu znači utvrditi elemente koji mogu pomoći u evangelizaciji, odnosno osobnom i duhovnom rastu, radi posebnoga sazrijevanja u sakramentalnoj milosti sakramenta ženidbe. ${ }^{29}$ Obitelj je danas u postmoderni na različite načine ugrožena i na razini odgoja vlastite djece. Najčešći je razlog nedostatak vremena za djecu zbog prezaposlenosti. Djeca rastavljenih i civilno vjenčanih brakova dodatno su opterećena nazočnošću, a time odgojem oca ili majke koji nisu biološki otac ili majka. Djeca takvih roditelja osjećaju često nedostatak ljubavi, zapostavljenost, emocionalno su uskraćena za ljubav odsutnoga oca ili majke, teško se socijaliziraju, posebice teško iskazuju svoje osjećaje i dolaze u dodir s njima, tjeskobna su, prožeta strahom pred budućnošću, predisponirana za

\footnotetext{
${ }^{24}$ Usp. isto, br. 33, 25.-26.

${ }^{25}$ http://w2.vatican.va/content/francesco/it/audiences/2015/documents/papa-francesco_ 20150527_udienza-generale.html (22.XI. 2016.).

${ }^{26}$ FRANJO, Obitelj je dragocjeno blago, 102.-103.

${ }^{27}$ Usp. P. ARAČIĆ, Radosna poruka krštenja, Osijek, 2016., 41.-46.

${ }^{28}$ Usp. AL, br. 293-294, 224.-225.

${ }^{29}$ Usp. XIV. OPĆA REDOVITA SKUPŠTINA BISKUPSKE SINODE, Relatio finalis - zaključno izvješće biskupske sinode, br. 71, 81.
} 
bijeg u vlastiti svijet, agresiju i ovisnosti te se u konačnici češće i lakše i sami kao odrasli rastaju, odnosno doživljavaju $\gg$ bračne brodolome $\ll .{ }^{30} \mathrm{Na}$ općoj audijenciji 7. siječnja 2015. godine papa Franjo nagovor posvećuje majkama. ${ }^{31} \mathrm{Za} \mathrm{njega} \mathrm{je} \mathrm{maj-}$ ka lijek koji može izliječiti ljudski individualizam, sebičnost, oplemeniti svako ljudsko srce sebedarjem, pružiti i dati život životu. Smatra da bez majki ne samo da ne bi bilo novih vjernika nego bi vjera izgubila i dobar dio svoje jednostavne i duboke topline. Zaključuje kako bi Crkva sa svojim pastoralnim djelovanjem trebala biti poput majke. ${ }^{32}$ Papa Franjo 28. siječnja 2015. i 4. veljače 2016. godine audijencije posvećuje današnjim očevima i njihovim poteškoćama u ostvarivanju očinstva. $U$ govoru o očevima posebno ističe suvremeni problem očinstva - odsutnost današnjih očeva zbog prezaposlenosti. Naime, prezaposlenost očeva onemogućava cjelovit odgoj djece. ${ }^{33}$ Važno je stoga da očevi sa svojim suprugama unatoč svemu nastoje dijeli radost i tugu, napor i nadu, posebice ljubav. Govoreći o odgoju u obitelji ističe: »Kucnuo je čas da se očevi i majke vrate iz svojega izgnanstva - jer su sami sebe prognali iz odgoja djece - i ponovno na sebe potpuno preuzmu svoju odgojnu ulogu. ${ }^{34}$ Djeca rastavljenih i civilno vjenčanih često su izgnana i prognana iz obiteljskoga gnijezda, te su zbog toga poseban pastoralni izazov za Crkvu i njezino pastoralno djelovanje. Pastoralni pristup, posebice djeci rastavljenih i civilno vjenčanih roditelja, treba biti poput odnosa majke i oca prema vlastitom djetetu. $U$ poosobljenom pastoralnom pristupu potrebno je nježno pristupati i naviještati Radosnu vijest spasenja. Papa je uvjeren da raznoliku i oprečnu stvarnost života postmoderne obitelji možemo shvatiti jedino u svjetlu evanđelja, a cjelokupno pastoralno djelovanje usmjeriti na čovjeka ako probudimo uspavanu Crkvu i današnjega vjernika. On smatra da zbog svijeta i mentaliteta koji sve više »bježi « od institucije braka i obitelji postojeće pastoralno djelovanje i današnja pastoralna praksa ne smije ostati takva kakva jest, nego je nužna pastoralna i misijska preobrazba. ${ }^{35} \mathrm{U}$ tom je kontekstu u Crkvi potrebno probuditi i osvježiti interes za ozbiljnu pripremu mladih na ženidbu i za njihovu pratnju i podršku u prvim godinama bračnoga života, posebice u kriznim situacijama. Svećenici u pastvi i djelatnici u savjetovali-

\footnotetext{
${ }^{30}$ Usp. K. NIKODEM, P. ARAČIĆ, Obitelj u transformaciji, u: J. BALOBAN (ur.), U potrazi za identitetom, 145.-175.

${ }^{31} \mathrm{http}: / /$ w2.vatican.va/content/francesco/it/audiences/2015/documents/papa-francesco_ 20150107_udienza-generale.html (22.XI. 2016.).

${ }^{32}$ FRANJO, Obitelj je dragocjeno blago, 25.-28.

${ }^{33} \mathrm{http}$ ://w2.vatican.va/content/francesco/it/audiences/2015/documents/papa-francesco 20150128 _udienza-generale.html (22. XI. 2016.) i http://w2.vatican.va/content/francesco/it/ audiences/2015/documents/papa-francesco_20150204_udienza-generale.html (22.XI. 2016.).

${ }^{34}$ FRANJO, Obitelj je dragocjeno blago, 29.-36.

${ }^{35}$ Usp. EG, br. 26, 26.-27.
} 
štima pozvani su ozbiljno proučiti i produbiti sadržaj, poboljšati pastoralni pristup, produbiti vrjednote braka i obitelji mladom čovjeku, posebice odgajati za življenje, poštivanje te vrjednovanje braka i obitelji, crkvenoga nauka i Božjega nauma. Crkveni nauk o ženidbi i obitelji treba biti u središtu evangelizacije i predmet pronicljivoga produbljivanja. ${ }^{36} \mathrm{Na}$ općoj audijenciji 17. prosinca 2014. godine, govoreći o nazaretskoj obitelji, papa Franjo ističe osnovne postavke teologije obiteljskoga života. U nagovoru upotrebljava vrlo jednostavnu sliku velikoga značenja, posebice u pastoralnom smislu s obzirom na rastavljene i civilno vjenčane. ${ }^{37}$ Citirajući Ivanovo evanđelje (Iv 1, 46) u kojem piše: »Iz Nazareta da može biti što god dobro? «, naglašava kako je Nazaret ozloglašena periferija te da je sam Bog izabrao periferiju. Bračno-obiteljska periferija jest svaki brak i svaka obitelj koja se nalazi u krizi, posebice rastavljeni i civilno vjenčani. Crkva zbog toga treba napustiti statički pastoral, pastoral očuvanja, te izići na periferije ${ }^{38}$ jer su rastavljeni i civilno vjenčani eklezijalna sakramentalna pastoralna periferija i zbog toga su poseban izazov za cjelokupno pastoralno djelovanje. ${ }^{39}$

\section{Velika očekivanja, skromni zaključci za pastoral rastavljenih i civilno vjenčanih ? $^{40}$}

Budući da sve utječe na obitelj, kao što i obitelji utječu na svu stvarnost, složenost pobudnice prepoznaje se u preširokoj problematici. Za mnoge su pitanja kojima se bavila sinoda o obitelji 1980. godine te pobudnica Familiaris consortio (životno partnerstvo, sve veći broj razvoda, pravno neregulirani brakovi, kontracepcija, pobačaj, siromaštvo u Africi, poligamija, slobodne veze te proglašenje ženidbe ništavom) područja o kojima raspravlja i piše pobudnica pape Franje Amoris laetitia. Ono što je specifično za pobudnicu Amoris laetitia jest da su sinodalni oci koji su dolazili iz tzv. prvoga svijeta uglavnom imali pred sobom pitanje rastavljenih i civilno vjenča-

\footnotetext{
${ }^{36} \mathrm{http}$ // /www.nytimes.com/2016/04/08/world/europe/pope-francis-amoris-laetitia-family. html?_r=0 (25. X. 2016.).

${ }^{37}$ http://w2.vatican.va/content/francesco/it/audiences/2014/documents/papa-francesco_ 20141217_udienza-generale.html (22. XI. 2016.).

${ }^{38}$ Usp. I. MUSA, Neki »isusovački« pastoralni naglasci pape Franje, u: Diacovensia 22(2014.)4, 519.

${ }^{39}$ Vidi: http://www.catholicherald.co.uk/commentandblogs/2016/04/08/amoris-laetitia-five-keypassages-you-need-to-read/, (25. X. 2016.).

${ }^{40}$ Mnogi su sinodalni oci iz tzv. Prvoga svijeta došli s očekivanjima kako bi se trebala i morala promijeniti sakramentalna praksa s rastavljenima i civilno vjenčanima. To znači da bi se u određenim okolnostima i pod određenim uvjetima rastavljeni i civilno vjenčani mogli ispovijedati i pričestiti. Nakon što pobudnica nije donijela izričito dopuštenje, mnogi su zaključili kako se od redovite sinode mnogo očekivalo, a skromno zaključilo, odnosno donijelo novo za pastoralnu praksu. Zbog toga je autor rada stavio takav naslov s upitnikom.
} 
nih te pitanje stava Crkve prema istospolnim zajednicama ${ }^{41}$, dok su s druge strane sinodalni oci iz tzv. drugoga svijeta (Afrike i Azije) pred sobom imali pastoralna iskustva u kojima se obitelj susreće s ratovima, siromaštvom, progonima, trgovinom ljudima, ugovorenim brakovima, međureligijskim brakovima, maloljetničkim zaručništvom, poligamijom, spolnim sakaćenjem žena i drugim problemima. ${ }^{42}$ Zbog takvih okolnosti ni jedna izvanredna i redovita biskupska sinoda nije bila tako medijski praćena kao što su bile posljednje dvije. Mnogi su imali, gledajući iz teološko-pastoralne perspektive, prevelika očekivanja, očekivali su velike promjene. Mediji i mnogi u Crkvi, posebice oni koji su članovi prvoga svijeta, najviše su očekivali moguće promjene i drukčiji stav vezan uz pastoralni pristup rastavljenima i civilno vjenčanima te istospolnim zajednicama. Pojedini teolozi smatraju da su upravo vrlo različiti teološki i pastoralni stavovi o obiteljskim pitanjima doveli papu Franju do problema kako argumentirati i potkrijepiti teološkim razlozima spomenute razlike. Na sinodi su bile dvije temeljne struje: konzervativna i progresivna struja. Konzervativci su ustrajavali na nerazrješivosti braka, a progresivni sinodalni oci naglašavali su kako uviđaju da postoje milijuni dobrih ljudi koji žive u drugom braku i kojima se uskraćuje pristup sakramentima, a za takvu situaciju nisu krivi, stoga njihov stav o mogućem sakramentalnom životu rastavljenih i civilno vjenčanih nije želio mijenjati crkveni nauk, nego pastoralnu praksu. Budući da je, prema Papinim kritičarima, izostala istančana egzegeza ulomaka iz Svetoga pisma koji govore o braku i obitelji, kao i iznošenje crkvenoga nauka, teolozi zamjeraju što se manje teološki raspravljalo, a više pastoralno usmjeravalo. ${ }^{43}$ Pastoralna praksa $s$ rastavljenima i civilno vjenčanima cijelo je vrijeme bila vrući krumpir koji je postavljao pitanje može li se u određenim okolnostima i nekim slučajevima omogućiti i dopustiti pričest razvedenim i ponovno civilno vjenčanim osobama. Odgovor se ne može razumjeti bez Papina poziva na pozorno razlučivanje i praćenje svake pojedinačne situacije, posebice nikad na štetu svjedočenja o nerazrješivosti ženidbe ${ }^{44}$. Kardinal W. Kasper iznio je stav da bi o pitanju rastavljenih i ponovno vjenčanih trebalo slijediti primjer pravoslavnih crkava. ${ }^{45}$ Pojedini oci predlagali su in foro in-

${ }^{41}$ http://www.crisismagazine.com/2016/amoris-laetitia-retreat-absolute-moral-norms, (25.X. 2016.).

${ }^{42}$ Usp. T. J. REESE, Podijeljena sinoda do hromog zaključka, u: Concilium 52(2016.)2., 183.-184.

${ }^{43}$ Usp. isto, 184.

${ }^{44}$ Pobudnica upućuje na postojanje situacija u kojima osobe koje objektivno žive u stanju grijeha možda subjektivno i nemaju krivnju. Usp. J. KOLEGA, Poslanje obitelji: ljubav u radosti, u: Zvona, mjesečnik za kršćansku kulturu 54(2016.) 5, 25.

${ }^{45}$ Brak je nerazrješiv sve dok odgovara svim osobinama jer se bračni drugovi međusobno obavezuju na doživotnu vjernost. Raskinuti bračnu vezu može ili smrt ili nekakav drugi uzrok koji će nadvladati crkveni stav o nerazrješivosti braka. $S$ obzirom na fizičku smrt ili neki drugi uzrok koji ruši osnove braka razlikuje se prestanak braka bez presude i prestanak braka po presudi ili razvod. Bez presude brak prestaje smrću, proglašenjem jednoga bračnoga druga mrtvim, polaganjem monaš- 
terno pri kojem bi svećenik pomogao osobi da se izmiri s Crkvom. Jednostavnije rečeno, pastoralni djelatnici, napose svećenici, prema pobudnici Amoris laetitia pozvani su rastavljenima i civilno vjenčanima pomoći postati svjesnima osobnoga stanja pred Bogom te ih dovesti do odluke o tome što će činiti i kako dalje živjeti. Naime, u oblikovanju ispravne odluke rastavljenih i civilno vjenčanih razgovor sa svećenicima omogućio bi snažnije i cjelovitije sudjelovanje u životu Crkve. ${ }^{46}$ Kako bi se dovelo do svijesti osobnoga stanja pred Bogom i samim čovjekom, Amoris laetitia iznosi preduvjete: poniznost, diskreciju i ljubav prema Crkvi i njezinu nauku koji su u cijelosti prožeti ispunjavanjem Božje volje. Konzervativni teolozi govore da ništa novo nije doneseno jer se ne spominje pričest, dok s druge strane progresivni tvrde suprotno. Premda se pričest izrijekom ne spominje, razgovor in foro interno otvara takvu mogućnost. Za svoj stav progresivni uzimaju argument: zašto uopće spominjati in foro interno ako upravo on ne omogućava pričest i potpuno zajedništvo. ${ }^{47}$ I kod jednih i kod drugih sinodskih otaca, a tako i kod pojedinih mjesnih Crkava, razgovor in foro interno sa svojim bogatim sadržajem, ali u sebi do kraja nedorečenim, stvorio je određenu zbrku, zato ga je Papa morao kasnije pojašnjavati. Tome je dokaz pismo argentinskim biskupima koji su to shvatili kao mogućnost ispovijedi i pričesti rastavljenih i civilno vjenčanih. ${ }^{48} \mathrm{U}$ svakom slučaju, papa Franjo unaprijedio je prema pobudnici Amoris laetitia sinodalni proces, otvorio raspravu i ukazao na potrebu posvećivanja više vremena rastavljenima i civilno vjenčanima. U tom smislu sinoda nije bila tek događaj, već način djelovanja kojim bi trebala biti prožeta Crkva, a to znači: hrabro, otvoreno doći u Nazaret, odnosno periferiju. ${ }^{49}$

\section{Pratiti, razlučivati i integrirati slabosti rastavljenih $i$ civilno vjenčanih prema pobudnici Amoris laetitia}

Pastiri su pozvani odgovornim i ozbiljnim razlučivanjem pratiti i prosuditi sazrijevanje savjesti. Na taj način moguće je barem djelomično pratiti, razlučivati i integrirati rastavljene i civilno vjenčane u krilo Crkve i župne zajednice. Pri tome

koga zavjeta i rukopoloženjem za episkopa. Uzroci razvoda braka u zakonodavstvu Pravoslavne Crkve jesu: 1. Preljub (stvarni, preuzumptivni i fiktivni), 2. Kada je riječ o životu bračnoga druga, 3. Namjerno učinjen abortus, 4. Zlobno napuštanje bračnoga druga, 5. Nestanak bračnoga druga, 6. Tjelesna i duševna bolest, 7. Moralna pokvarenost kao uzrok razvoda, 8. Otpadništvo od pravoslavne vjere, 9. Isključenje jednoga bračnoga lica iz Pravoslavne Crkve. Usp. J. NIKOLIĆ, Razvod braka u Pravoslavnoj crkvi, u: Bogoslovska smotra 49(1979.)1-2., 182.-186.

${ }^{46}$ Usp. T. J. REESE, Podijeljena sinoda do hromog zaključka, 186.

${ }^{47}$ Usp. isto, 187.

${ }^{48} \mathrm{http}$ // en.radiovaticana.va/news/2016/09/12/pope_endorses_argentine_bishops_document on_amoris_laetitia/1257635 (25.X.2016.).

${ }^{49}$ Usp. isto. 
je potrebno povezati savjest s crkvenim naukom i praksom, pomagati sazrijevanju dobro oblikovane savjesti i paziti na sablazan kod vjernika. Temeljni kriterij jest evanđeosko milosrđe, a rješenje je u provjerenim pojedinačnim slučajevima u kojima konačnu riječ ima Crkva kojoj je vjernik pozvan suobličiti sud vlastite savjesti. ${ }^{50}$

\subsection{TEOLOŠKO-PASTORALNI RAZLOZI ZA PRAĆENJE, RAZLUČIVANJE I INTEGRACIJU RASTAVLJENIH I CIVILNO VJENČANIH}

Stvarnost praćenja, razlučivanja, nazočnosti i moguće, barem djelomične, integriranosti rastavljenih te civilno ponovno vjenčanih, prema pobudnici, leži u činjenici da se Crkva mora s ljubavlju okrenuti prema onima koji na bilo koji način sudjeluju u njezinu životu. ${ }^{51} \mathrm{Na}$ tragu pape Benedikta XVI., koji ističe kako nema jednostavnoga recepta za teološko-pastoralni pristup rastavljenima i civilno vjenčanima, papa Franjo poziva pastire da s posebnom osjetljivošću pristupaju periferiji bračno-obiteljske stvarnosti, posebice nastojeći produbiti njihovu pripadnost Kristu i Crkvi. On vrlo slikovito, ali sadržajno govori kako Crkva, pastoralo nastojanje, župne zajednice, predvoditelji župnih zajednica te ostali pastoralni djelatnici trebaju pristupati rastavljenima i civilno vjenčanima. ${ }^{52}$ Oni trebaju rastavljenima i civilno vjenčanima biti:

1. svjetionik

2. luka

3. baklja

4. poljska bolnica

5. Crkva prožeta obiteljskim duhom

6. kvasac. ${ }^{53}$

Svaka slika snažno govori kakva Crkva treba biti i kakvo treba biti pastoralno djelovanje prema rastavljenima i civilno vjenčanima. Ako pastoralno djelovanje i pastoralni djelatnici, napose svećenici, u duhu evanđelja pristupaju rastavljenima i civilno vjenčanima, oni će zasigurno produbljivati pripadnost Kristu i Crkvi molitvom, slušanjem Božje riječi, sudjelovanjem u liturgiji, kršćanskim odgojem djece, ljubavlju i služenjem siromašnima, zauzimanjem za pravdu i mir. ${ }^{54}$ Naime, svako $z$ dravo tkivo Crkve treba biti prožeto Duhom Svetim i zakonom postupnosti. Zakon postu-

\footnotetext{
${ }^{50}$ Usp. AL, br. 291, 222.

${ }^{51}$ Usp. P. ARAČIĆ, Trauma rastave i razvoda braka i obitelji, Osijek, 2016., 133.-142.

${ }^{52}$ Usp. AL, br. 291-292, 222.-223.

${ }^{53}$ Usp. isto.

${ }^{54}$ Usp. FRANJO, Obitelj je dragocjeno blago, 121.-123.
} 
pnosti ${ }^{55}$ nije novum u pastoralu braka i obitelji jer je i papa Ivan Pavao II. u pobudnici Obiteljska zajednica ${ }^{56}$ isticao da to nije postupnost zakona, nego postupnost u mudrom slobodnom činjenju pojedinaca koji nisu sposobni razumjeti, cijeniti ili potpuno provoditi u djelo objektivne zahtjeve zakona. Zakon je sam po sebi Božji dar koji pokazuje put, dar za svakoga bez iznimke. Dimenzija odnosa, pristupa, prosuđivanja, a napose razlučivanja neredovitih situacija u povijesti Crkve obilježena je dvama načelima: marginalizacijom i reintegracijom. Jeruzalemski sabor udario je temelje Isusovu putu integriranja svih ranjenih, i rastavljenih i civilno vjenčanih, put milosrđa i novoga početka, neosuđivanja, izlijevanja balzama: »Božjeg milosrđa na sve one koji to iskrena srca traže... jer prava je ljubav uvijek nezaslužena, bezuvjetna i besplatna! $\ll{ }^{57}$ Naime, riječ je o tome kako Crkva ne smije samo izbjegavati prosudbe koje zanemaruju okolnosti zbog kojih osobe trpe, nego treba omogućiti osobama koje su rastavljene i civilno vjenčane osobnu dimenziju sudjelovanja u crkvenoj zajednici. Načini sudjelovanja u župnoj zajednici mnogobrojni su, od angažiranosti u župnom karitasu do katehizacije. Dakle, zadaća je Crkve objaviti Božju pedagogiju milosti, a Božja pedagogija milosti nadilazi i one koji smatraju da su u punom zajedništvu s Crkvom. Stoga Papa nastoji velikodušnom otvorenošću, osluškivanjem i osobnim kršćanskim zauzimanjem pokazati svu širinu prihvaćanja svake osobe u Crkvu. Dva razloga za takav pastoralni pristup iznio je prije pape Franje papa emeritus Benedikt XVI.: objektivno zlo ne mora uvijek značiti subjektivni osobni grijeh i djeca koja dolaze iz takvih neredovitih situacija očekuju, traže i zahtijevaju prihvaćenost od Crkve kakvu nalaže Krist. ${ }^{58}$ Razumijevanje te put sazrijevanja u razumijevanju poseban je pastoralni zadatak Crkve. Nerazumijevanje koje dovodi do loma i sloma bračno-obiteljskoga života doživljavaju ne samo osobe koje su se rastale i civilno vjenčale i njihova djeca nego i gotovo svi koji su na bilo koji način dio njihova života, počevši od njihovih roditelja, braće i sestara pa do cijele župne zajednice. ${ }^{59}$ Pastoralom uključivanja stvara se radosno i plodonosno iskustvo i za onoga tko je rastavljen i civilno vjenčan. Za takav pastoralni pristup i djelovanje najsnažniji argument jest taj da se nitko ne smije osjećati izopćenim, nego kao živi ud Crkve. ${ }^{60}$ Logika uključivanja pretpostavlja odgovorno pastoralno razlučivanje u pojedinom zaključivanju i to od slučaja do slučaja. Predvoditelj zajednice dužan

\footnotetext{
${ }^{55}$ Usp. AL, br. 291, 222.

${ }^{56}$ IVAN PAVAO II., Familiaris consortio, 1981., Zagreb, br. 34, 48.-49. (= FC).

${ }^{57}$ AL, br. 296, 227.

${ }^{58}$ https://w2.vatican.va/content/benedict-xvi/en/speeches/2012/june/documents/hf_ben-xvi_ spe_20120602_festa-testimonianze.html (28. XI. 2016.)

${ }^{59}$ Usp. FRANJO, Obitelj je dragocjeno blago, 117.-119.

${ }^{60}$ Usp. AL, br. 299-300, 229.-230.
} 
je savjetovati i osobno razabrati stupanj odgovornosti rastave rastavljene i civilno vjenčane osobe u skladu s naukom Crkve i biskupovim smjernicama. ${ }^{61}$

Prema papi Franji postoje tri teološko-pastoralna razloga za integraciju rastavljenih i civilno vjenčanih u Crkvu i župnu zajednicu:

a) prepoznati Božju milost koja djeluje u svakoj osobnosti ${ }^{62}$

b) hrabro svjedočiti kako Bog ostvaruje dobro u svakoj osobnosti koja je usmjerena na dobro ${ }^{63}$

c) ljubavlju se brinuti za sve osobe koje su u službi mjesne i župne zajednice i koje žive i ostvaruju vlastite karizme. ${ }^{64}$

\subsection{IN FORO INTERNO ${ }^{65}$ - ZNAČENJE I SADRŽAJ}

Razgovor sa svećenikom in foro interno mora rastavljenima i civilno vjenčanima pomoći u stvaranju ispravnih sudova o zaprekama punoga zajedništva s Crkvom. Pri razgovoru svećenika i rastavljene civilno vjenčane osobe svećenik je dužan osvijestiti i analizirati njezino:

1. ophođenje s djecom nakon što je prvi ženidbeni savez zapao u teškoće

2. intenzitet i napor te nastojanje oko pomirenja

3. suodnos s bračnim drugom s kojim je savez prekinut

4. posljedice na ostatak obitelji

5. posljedice koje osjeća zajednica vjernika

6. kakav primjer pruža mladima koji se pripremaju na ženidbu. ${ }^{66}$

I sveti Ivan Pavao II. u svojoj apostolskoj pobudnici Obiteljska zajednica istaknuo je da Crkva ozbiljno promišlja kako ublažiti specifične situacije rastavljenih i civilno vjenčanih osoba ${ }^{67}$ Katekizam Katoličke Crkve ističe: »Ubrojivost i odgovornost za neki čin mogu se umanjiti ili poništiti neznanjem, nepažnjom, nasiljem, strahom, navikama, neumjerenim strastima i drugim psihičkim ili društvenim čimbenicima

\footnotetext{
${ }^{61} \mathrm{http}: / /$ w2.vatican.va/content/francesco/it/audiences/2015/documents/papa-francesco_ 20150805_udienza-generale.html (22. XI. 2016.); usp. AL, br. 300, 231.

${ }^{62}$ Usp. AL, br. 291, 222.

${ }^{63}$ Usp. isto.

${ }^{64}$ Usp. isto, br. 291, 222.

${ }^{65}$ Usp. isto, br. 300, 230.-232.

${ }^{66}$ Usp. isto, 230.-231.

${ }^{67}$ Usp. FC, br. 84, 113.-115.
} 
koji ublažuju moralnu odgovornost«, a opširno spominje i čuvstvenu nezrelost, snagu stečenih navika, stanje tjeskobe i druge psihičke ili društvene čimbenike ${ }^{68}$.

\subsubsection{Dužnosti predvoditelja zajednice u pastoralnom radu s rastavljenima i civilno} vjenčanima in foro interno ${ }^{69}$

a) Osobni razgovori i praćenje svećenika s rastavljenima i civilno vjenčanima mora omogućiti ispravan sud o poteškoćama i zaprekama punoga sudjelovanja u životu Crkve. Zatim treba stvarati pozitivne korake koji će pogodovati, omogućavati i pospješiti pastoralno djelovanje pastorala rastavljenih i civilno vjenčanih osoba. ${ }^{70}$ Ispravan sud dogodit će se ako se ostvari kvalitetan personalizirani pastoral koji zahtijeva susret, slušanje, dijalog, poosobljenu formaciju ispravne savjesti i integraciju slabosti. ${ }^{71}$

b) Svećenik je u razgovorima s rastavljenima i civilno vjenčanima dužan osvijestiti kako doživljavanje osobnih teškoća zbog rastave nužno zahtijeva otkrivanje djelomičnih krjeposti koje rastavljeni i civilno vjenčani mogu ostvariti u osobnom životu i župnoj zajednici. ${ }^{72}$

c) Odgoj svijesti o grijehu, grješnosti i osobnoj krivnji u pastoralu rastavljenih i civilno vjenčanih treba biti ugrađen u praksu Crkve. Istina i svjetlo svemu daju smisao i vrijednost. Istina je svjetlo i razuma i vjere. Naravna i nadnaravna Istina zahvaća i pruža te daruje snagu života na putu istine. ${ }^{73}$ Razgovor svećenika in foro interno treba rastavljene i civilno vjenčane dovesti do svijesti vlastitoga stanja pred Bogom. ${ }^{74}$

d) Svećenikovo uskogrudno promatranje rastavljenih i civilno vjenčanih nije u duhu pastoralne razboritosti i kvalitetnoga pastoralnoga djelovanja, posebice ako svećenik nije ugradio in foro interno pastoralno razlučivanje, raspoznava$\mathrm{nje}^{75}$, prosudbu i praćenje. Brza rješenja i djelomični odgovori trebaju postati zaborav. Narav je izvor objektivnoga nadahnuća koje se nalazi u temelju donese-

${ }^{68}$ Katekizam Katoličke crkve, Zagreb, 1994., br. 1735, 450.

${ }^{69}$ Usp. AL, br. 300, 230.-232.

${ }^{70}$ Usp. isto, 231.

${ }^{71}$ Usp. A. ČONDIĆ, Papa Franjo: naglasci i perspektive obiteljskog pastorala, u: Vjesnik Đakovačkoosječke nadbiskupije i Srijemske biskupije 145(2017.)1, 17.

72 Usp. AL, br. 300, 232.

${ }^{73}$ Usp. BENEDIKT XVI, Caritas in veritate, Zagreb, 2009., br. 3-4, 7.-9. (= CV).

${ }^{74}$ Usp. AL, br. 300, 232.

${ }^{75}$ Raspoznavanje nije samo pastoralni nego i teologalni i duhovni čin. Usp. N. VRANJEŠ, Pastoralni projekt, programiranje i metodologija u crkvenom djelovanju. Doprinos razvitku programskoga pastoralnoga djelovanja, u: Diacovensia 17(2009.)2, 292.-294. 
ne odluke u svakoj situaciji, a tako i kod rastavljenih i civilno vjenčanih. ${ }^{76}$ Granica koja se nalazi u prostoru Božjega nauma nikada nije konačna, nego je u službi pronalaska odgovora Bogu, a time onda i u službi rasta svakoga čovjeka unutar njegovih osobnih granica. ${ }^{77}$

e) Via caritatis (usp. Iv 15, 12) temeljni je put i način razgovora svećenika in foro interno s rastavljenima i civilno vjenčanima. ${ }^{78}$ Sam Petar ističe da ljubav pokriva

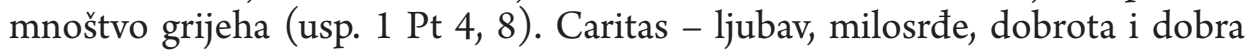
djela, sve to ulazi u bit kršćanskoga života. ${ }^{79} \mathrm{Ljubav} u$ istini glavna je pokretačka snaga rasta i sazrijevanja svake osobe. Ljubav čiji je izvor u Bogu, posvemašnoj Istini, potiče osobe na hrabro susretanje s osobnom istinom. Bez ljubavi u Istini nije moguće cjelovito ostvariti razgovor svećenika in foro interno s rastavljenima i civilno vjenčanima. ${ }^{80}$

f) Osobni, psihološki, povijesni, biblijski i teološki temelji ne bi trebali umanjiti vrijednost evanđeoskoga ideala za pastoralno djelovanje: pastoralno pratiti rast, sazrijevanje, radost i nadu, žalost i tjeskobu današnjih rastavljenih i civilno vjenčanih. ${ }^{81}$ Isus je pastir ne devedeset i devet, nego sto ovaca. To znači da Crkva ima zadatak naviještati Božje milosrđe, ${ }^{82}$ biti živo srce koje dopire do svakoga srca i uma, napose biti znak Božjega kraljevstva. ${ }^{83}$ Svećenik u razgovoru in foro interno treba imati na umu izgubljenu ovcu koju je potrebno neprestano tražiti.

g) Konkretnim djelovanjem kroz konkretnu stvarnost ne ukazivati na blatom zaprljane cipele s ulice, nego stavom suosjećanja prema osobama u blatu izbjegavati proganjanje, oštre i brzoplete sudove. ${ }^{84}$ Svećenik mora biti svjestan kako nije kontrolor milosti ni carinik milosrđa, nego predstavnik Crkve koja je Očev dom, dom u kojem ima mjesta za svakoga, bez obzira na životne tegobe. Naime, oko rastavljenih i civilno vjenčanih lomila su se i lome se koplja na polju morala, prava, dogmatike, posebice pastoralne teologije i crkvene prakse. ${ }^{85}$

\footnotetext{
${ }^{76}$ https://www.ncronline.org/news/theology/amoris-laetitia-francis-model-conscience-empowers-catholics (25. X. 2016.)

${ }^{77}$ Usp. AL, br. 298, 228.

${ }^{78}$ Usp. isto, br. 300, 232.

${ }^{79}$ M. ŠKVORC, Jeruzalem ili Antiohija, Zagreb, 1988., 341.-242.

${ }^{80}$ Usp. CV, br. 1-2, 5.-7.

${ }^{81}$ Usp. DRUGI VATIKANSKI KONCIL, Gaudium et Spes. Pastoralna konstitucija o crkvi u suvremenom svijetu (7. XII. 1965.), br. 1, u: Dokumenti, Zagreb, ${ }^{72008 ., ~ s t r . ~ 651 . ~(=~ G S) . ~}$

${ }^{82}$ Usp. FRANJO, Amoris laetitia, isto, br. 300., str. 231.

${ }^{83}$ Usp. FRANJO, Miseriecordiae vultus, Zagreb, 2015., br. 12, 18.-19. (= MV).

${ }^{84}$ Usp. AL, br. 300, 232.

${ }^{85}$ Usp. V. RELJAC, Pastoral braka i obitelji na iskušenju, Zagreb, 2011., 164.-165.
} 
h) Moralna teologija i teolozi i pastoralci, prema papi Franji, moraju paziti na cjelovitost moralnoga nauka Crkve. Pri tome se ni moralni teolozi ni svećenici u župnim zajednicama ne bi smjeli postaviti kao predstavnici Crkve koja uvjetuje milosrđem. ${ }^{86}$ Papa smatra da Crkva u mnogim područjima promišljanja i djelovanja zaboravlja besplatnu ponudu Božje ljubavi. Po njemu je moralna teologija danas prožeta hladnim birokratskim moralom koji onemogućava pastoralu i pastoralnim teolozima prostor za ostvarivanje i pružanje bezuvjetne Božje ljubavi. ${ }^{87}$ Liberalna struja tijekom sinode inzistirala je na pojedinim područjima pastoralne prakse koja nužno moraju napustiti hladni birokratski moral. Papa poziva vjernike, biskupe i svećenike da s povjerenjem, otvoreno razgovaraju o složenim situacijama u kojima su se mnogobrojni kršćani zatekli. Posebno poziva crkvene pastire da nastoje razumjeti današnjega čovjeka, napose da prepoznaju njegovo mjesto i mogućnosti, posebice što Crkva za njih može učiniti. ${ }^{88}$ Svjestan kako bi moglo doći do nesporazuma, naglašava kako svaki svećenik ne može na brzinu riješiti slučaj i ishoditi sakramentalne povlastice u zamjenu za usluge, nego je potreban dovoljno dug proces i vrijeme u kojem će svećenik i rastavljena i ponovno civilno vjenčana osoba moći upoznati cjelokupnu istinu. ${ }^{89}$

\section{Umjesto zaključka}

Pobudnica Amoris laetitia obuhvaća široku problematiku o obitelji od biblijskoga utemeljenja, sadašnje situacije u kršćanskim obiteljima, ljubavi u braku, pristupa neredovitim situacijama, sve do bračne i obiteljske duhovnosti. Prevelika očekivanja i traženje korjenitih promjena uzrok su neshvaćanja i površnoga tumačenja naizgled skromnih zaključaka pobudnice. Papa Franjo s posebnom pažnjom pristupa rastavljenima i ponovno civilno vjenčanima, očinskom ljubavlju poziva ih da pristupe svojim pastirima, prezbiterima, savjetuju se te pokušaju pronaći način kako se integrirati u život Crkve. Dokument na više mjesta upućuje na situacije u kojima osobe koje objektivno žive u stanju grijeha možda subjektivno i nemaju krivnju. Amoris laetitia posebno ističe nekoliko temeljnih postavki koje rastavljeni trebaju imati na srcu, a time i sama pobudnica pomaže svećenicima u ostvarenju onoga što pobudnica nalaže. Rastavljenima i civilno vjenčanima predvoditelji zajednica, svećenici i pastoralni djelatnici trebaju s pomoću prementaliziranoga pastoralnoga pristupa ostvarivati temeljnu zadaću Crkve - objavljivanje Božje pedagogije milosti te svjedočenje Radosne vijesti spasenja svakoj obitelji bez obzira je li doživjela

\footnotetext{
${ }^{86}$ Usp. AL, br. 311, 242.-243.

${ }^{87}$ Usp. isto, br. 312, 243.-244.

${ }^{88}$ Usp. http://www.americamagazine.org/issue/top-ten-takeaways-amoris-laetitia (25. X. 2016.).

${ }^{89}$ Usp. AL, br. 300, 232.
} 
brodolom $^{90}$ ili se nalazi u redovitim okolnostima. Svećenicima su naznačene i upute te postavljeni kriteriji za razgovor in foro interno. Razgovor in foro interno uključuje veliku angažiranost svećenika i osoba koje su rastavljene i ponovno civilno vjenčane kako bi se rastavljeni i ponovno civilno vjenčani što kvalitetnije približili punom zajedništvu s Crkvom i župnom zajednicom. U tom je smislu pobudnica Amoris laetitia svojevrstan priručnik za brak i obitelj. Neke će nadahnuti i oduševiti, nekima dati nadu, a neke razočarati. Pobudnica će biti uspješna ako raspravu o braku i obitelji preseli iz sinodalnih dvorana u župne zajednice, na periferiju i same brakove i obitelji.

\footnotetext{
${ }^{90}$ Brodolom u tom kontekstu slika je za one osobe koje su se rastale i civilno vjenčale ili one koje su se rastale i ostale same živjeti.
} 
S. Šota, Pastoralno djelovanje s Rastavljenima i Civilno ..., Str. 285.-301.

\title{
PASTORAL WORK WITH THE DIVORCED AND CIVILLY MARRIED ACCORDING TO THE APOSTOLIC EXHORTATION AMORIS LAETITIA
}

\author{
Stanislav ŠOTA*
}

Summary: Pope Frances has made a unique step in the Church by convening two consecutive Synods of Bishops on the family and thereby showed that family is his high priority and a pastoral challenge. The apostolic exhortation Amoris Laetitia has attracted great attention in the church and secular circles, especially the eighth chapter which discusses how to accompany, discern and integrate the weaknesses of the divorced and civilly married. The Pope begins with a concrete pastoral situation which he then theologically forms and interprets, making this kerygmatic approach key for understanding the exhortation. The Pope is especially concerned with the difficulties faced by the modern family, and he approaches families in >irregular « situations as a merciful father who listens to them, accepts them, and offers them ways of integration. Pre-mentalization is necessary, especially with leaders of parish communities, priests, and other pastoral workers. The priest's accompaniment of the divorced and civilly married in foro interno should allow for the right judgement of the difficulties and obstacles for full participation in the life of the Church, and create positive steps that need to benefit, enable and improve pastoral work. The manifestation of difficulties in achieving sacramental grace in the sacrament of marriage necessarily demands discovering partial virtues which the divorced and civilly married can realize. The narrow-minded observation that doesn't involve pastoral discernment, judgement and accompaniment requires an advancement of pastoral activities. The pastoral care should not be static but creative and enthusiastic, infused with advances that allow for the proclamation of divine pedagogy of grace to every man.

Keywords: Amoris Laetitia, accompany, discern, integrate, the divorced and civilly married, marriage, in foro interno.

\footnotetext{
* Asst. Prof. Stanislav Šota, Ph. D., Catholic Faculty of Theology in Đakovo, J. J. Strossmayer University of Osijek, P. Preradovića 17, 31400 Đakovo, Croatia, stanislav.sota@os.t-com.hr
} 